\title{
Potential Cracking in Hydrogen Plant with Light Feedstocks (Part II)
}

\author{
Guotai Zhang, Sanjeev Sekhri \\ Process Department, Technip Stone \& Webster Process, Technology Inc., Claremont, USA \\ Email: gzhang@technip.com, ssekhri@technip.com
}

Received 2 June 2015; accepted 15 October 2015; published 22 October 2015

\begin{abstract}
This paper presents the analysis of potential thermal cracking of light feedstocks in the SMR. Two different feedstocks, natural gas and light hydrocarbon (HC) feedstock at two different mixed feed inlet temperatures, are selected to study the HC thermal cracking. Effect of Crossover Piping Volume on feed thermal cracking is also discussed.
\end{abstract}

\section{Keywords}

Steam-Methane Reformer (SMR), Temperature Index (TI), Mixed Feed Preheater (MFPH), Crossover Piping Volume (CPV), Hydrocarbon (HC) and Thermal Cracking Kinetics

\section{Introduction}

$\mathrm{H}_{2}$ can be produced from a variety of HC's, ranging from natural gas (methane) to petroleum-based gases and liquids. In our previous paper (Part I), we had quantitatively discussed thermal cracking of Liquefied Natural Gas (LNG), $\mathrm{C}_{4}$ stream and naphtha feed stocks in the CPV of reformer [1] [2].

Parameters that affect thermal cracking are HC feed composition and component structure, mixed feed (HC + Steam) reformer inlet temperature and pressure, Steam/C mole ratio and mixed feed residence time in the CPV, etc. [3].

Natural gas is an important feed stock for SMR, however it is not a commodity with uniform composition and it includes $\mathrm{N}_{2}, \mathrm{CO}_{2}, \mathrm{CH}_{4}$ and non-methane $\mathrm{HC}$ 's.

The objective of this study is to explore the parameters which will affect the undesired cracking of reformer feed stocks in the Mixed Feed Preheater (MFPH) coil and in the CPV. The parameters being considered are the mixed feed inlet temperature to the reformer and the residence time of mixed feed in the CPV. Also in this paper we introduce the concept of Temperature Index (TI) to indicate the thermal cracking potential of HC's.

HC feed is mixed with process steam and this stream is called mixed feed. The mixed feed is preheated in the MFPH Coil located in the convection section, and the preheated mixed feed is sent to the catalyst tubes through crossover piping (Figure 1).

\section{Basis of Analysis}

1) Scope 


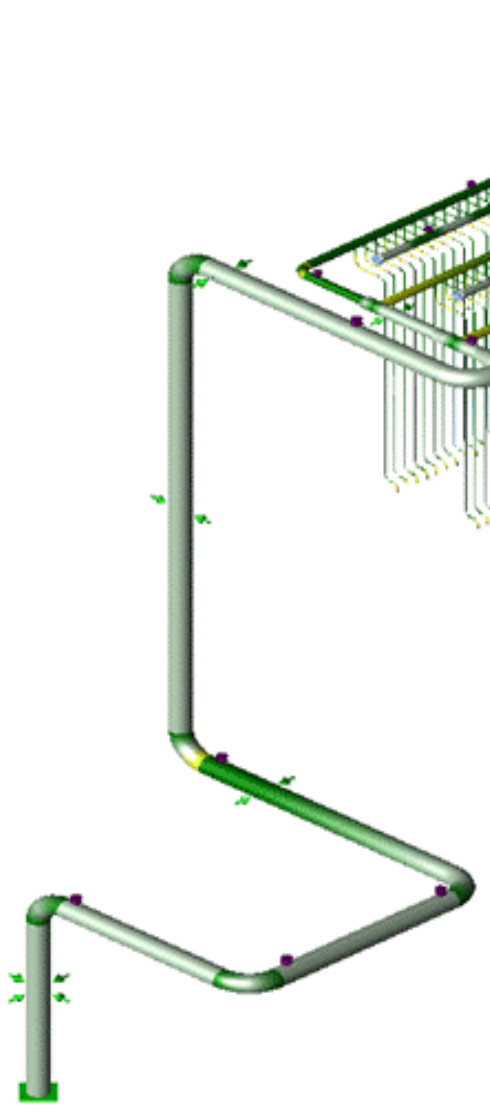

(a)
Code Stress Ratio by Percent (\%)

$\square>100 \%$

$>80 \%$

$\square>60 \%$

$>40 \%$

$\square>20 \%$

$\square<20 \%$

Figure 1. Typical layout of crossover piping. (a) MFPH coil outlet from convection section; (b) To catalyst tubes in SMR.

This paper analyses potential of thermal cracking in the MFPH Coil and crossover piping from MFPH coil outlet to the inlet of SMR.

2) MFPH Coil

MFPH Coil geometry and tube material are listed below (Table 1) which are used in the simulation for all cases.

3) Feed Composition

Case 1 feed (Natural Gas) has $\mathrm{N}_{2}, \mathrm{CO}_{2}, \mathrm{CH}_{4}$ and non-methane hydrocarbons as shown in Table 2. The feed inlet temperature to the reformer is relative low.

Case 2 is a light feed which is treated in the pre-reformer. It has more $\mathrm{H}_{2}$ and $\mathrm{CO}_{2}, \mathrm{CH}_{4}$ and no $\mathrm{C}_{2}+$ hydrocarbons as shown in Table 3. The feed inlet temperature to the reformer can be relative high.

Table 4 and Table 5 below are the Mixed Feed Preheater Coil (MFPH) design bases for process gas and flue gas.

4) Crossover Piping Volume (CPV)

Assume CPV is an adiabatic zone with no heat loss. CPV is constant for all cases which is $24.7 \mathrm{~m}^{3}$ per SMR.

5) Pressure Drop

Assume $0.35 \mathrm{~kg} / \mathrm{cm}^{2}$ drop through CPV.

\section{Design Tool-SPYR0 ${ }^{\circledR}$ Program}

The SMR feedstock cracking kinetics has been simulated using SPYRO ${ }^{\circledR}$ program which is widely used by the industry for prediction of hydrocarbon cracking.

SPYRO $^{\circledR}$ is a unique program for prediction of cracking furnace effluent yields as well as overall performance of the furnace. SPYRO ${ }^{\circledR}$ is the only program which is based on the rigorous fundamental mathematical equations 
Table 1. MFPH coil specification.

\begin{tabular}{|c|c|c|c|c|c|}
\hline MFPH \# of Rows & Tube Size NPS & Hori/Vert Distance inch & Tubes per Row & No. of Passes & Tube Material \\
\hline 8 (outlet) & 3” Sch 80 & $8 / 6$ & 14 & 28 & \multirow{8}{*}{$\mathbf{8 0 0 H}$} \\
\hline 7 & 3" Sch 80 & $8 / 6$ & 14 & 28 & \\
\hline 6 & 3” Sch 80 & $8 / 6$ & 14 & 28 & \\
\hline 5 & $3 ”$ Sch 40 & $8 / 6$ & 14 & 28 & \\
\hline 4 & 3” Sch 40 & $8 / 6$ & 14 & 28 & \\
\hline 3 & 3” Sch 40 & $8 / 6$ & 14 & 28 & \\
\hline 2 & 3” Sch 80 & $8 / 6$ & 14 & 28 & \\
\hline 1 (inlet) & 3" Sch 80 & $8 / 6$ & 14 & 28 & \\
\hline
\end{tabular}

Note 1: Total 8 rows in MFPH coil. 2: Effective tube length $13.2 \mathrm{~m}$ for all tubes. 3: All tubes are bare. 4: Process gas and flue gas are in co-current flow.

Table 2. Case 1 feed composition.

\begin{tabular}{|c|c|c|c|}
\hline \multirow{2}{*}{ Composition } & \multirow{2}{*}{ MW } & \multicolumn{2}{|c|}{ Mixed Feed } \\
\hline & & Mol \% & Wt \% \\
\hline $\mathrm{H}_{2}$ & 2.0159 & 0.85 & 0.097 \\
\hline $\mathrm{N}_{2}$ & 28.014 & 0.55 & 0.874 \\
\hline $\mathrm{CO}_{2}$ & 44.01 & 0.49 & 1.224 \\
\hline $\mathrm{CH}_{4}$ & 16.043 & 26.00 & 23.669 \\
\hline $\mathrm{C}_{2} \mathrm{H}_{6}$ & 30.07 & 0.38 & 0.648 \\
\hline $\mathrm{C}_{3} \mathrm{H}_{8}$ & 44.097 & 0.05 & 0.125 \\
\hline $\mathrm{iC}_{4} \mathrm{H}_{10}$ & 58.124 & 0.01 & 0.033 \\
\hline $\mathrm{nC}_{4} \mathrm{H}_{10}$ & 58.124 & 0.01 & 0.033 \\
\hline $\mathrm{nC}_{6} \mathrm{H}_{14}$ & 86.177 & 0.01 & 0.049 \\
\hline $\mathrm{H}_{2} \mathrm{O}$ & 18.015 & 71.65 & 73.247 \\
\hline Total & & 100.00 & 100.000 \\
\hline MW & $\mathrm{Kg} / \mathrm{Mol}$ & & \\
\hline Steam/C & $\mathrm{Mol} / \mathrm{Mol}$ & & \\
\hline
\end{tabular}

Table 3. Case 2 feed composition.

\begin{tabular}{cccc}
\hline \multirow{2}{*}{ Composition } & MW & \multicolumn{2}{c}{ Mixed Feed } \\
\cline { 3 - 4 } & & Mol \% & Wt \% \\
\hline $\mathrm{H}_{2}$ & 2.0159 & 7.25 & 0.86 \\
$\mathrm{~N}_{2}$ & 28.014 & 0.57 & 0.94 \\
$\mathrm{CO}$ & 28.01 & 0.04 & 0.07 \\
$\mathrm{CO}_{2}$ & 44.01 & 2.22 & 5.75 \\
$\mathrm{CH}_{4}$ & 16.043 & 26.23 & 24.79 \\
$\mathrm{H}_{2} \mathrm{O}$ & 18.015 & 63.69 & 67.59 \\
$\mathrm{Total}$ & & 100.00 & 100.000 \\
$\mathrm{MW}$ & $\mathrm{Kg} / \mathrm{Mol}$ & & 16.976 \\
$\mathrm{Steam} / \mathrm{C}$ & $\mathrm{Mol} / \mathrm{Mol}$ & & 2.42 \\
\hline
\end{tabular}


Table 4. MFPH coil design basis (process gas data).

\begin{tabular}{|c|c|c|c|c|c|}
\hline & Units & \multicolumn{2}{|c|}{ Case 1} & \multicolumn{2}{|c|}{ Case 2} \\
\hline \multicolumn{6}{|c|}{ MFPH Inlet Stream } \\
\hline Pressure & $\mathrm{Kg} / \mathrm{cm}^{2}-\mathrm{a}$ & \multicolumn{2}{|c|}{39.4} & \multicolumn{2}{|c|}{39.3} \\
\hline Temp. & ${ }^{\circ} \mathrm{C}$ & \multicolumn{2}{|c|}{368.4} & \multicolumn{2}{|c|}{456.4} \\
\hline \multirow[t]{3}{*}{ Flow } & $\mathrm{Kmol} / \mathrm{h}$ & \multicolumn{2}{|c|}{7,212} & \multicolumn{2}{|c|}{6,557} \\
\hline & \multicolumn{3}{|c|}{ MFPH Outlet and Reformer Inlet Streams } & \multirow{2}{*}{ MFPH Outlet } & \multirow[b]{2}{*}{ SMR Inle } \\
\hline & & MFPH Outlet & SMR Inlet & & \\
\hline Pressure & $\mathrm{Kg} / \mathrm{cm}^{2}-\mathrm{a}$ & 38.4 & 38.0 & 38.3 & 37.9 \\
\hline Temp. & ${ }^{\circ} \mathrm{C}$ & 593.5 & 593.3 & 649.3 & 648.9 \\
\hline Resid.Time in CPV & Sec & \multicolumn{2}{|c|}{6.4} & \multicolumn{2}{|c|}{6.6} \\
\hline
\end{tabular}

Table 5. MFPH design basis (flue gas data).

\begin{tabular}{cccc}
\hline & Units & Case 1 & Case 2 \\
\hline Flue Gas & & & 1.0 \\
\hline Pressure & $\mathrm{Kg} / \mathrm{cm}^{2}-\mathrm{a}$ & 1.0 & 1001 \\
Temperature & ${ }^{\circ} \mathrm{C}$ & 1003 & 9310 \\
Flow & $\mathrm{Kmol} / \mathrm{h}$ & 10,540 & \\
Composition & $\mathrm{Mol} \%$ & & 20.54 \\
$\mathrm{CO}_{2}$ & & 19.15 & 0.71 \\
$\mathrm{Ar}$ & & 0.73 & 1.45 \\
$\mathrm{O}_{2}$ & & 1.63 & 59.84 \\
$\mathrm{~N}_{2}$ & & 61.59 & 17.46 \\
$\mathrm{H}_{2} \mathrm{O}$ & 16.90 & 100.00 \\
$\mathrm{Total}^{2}$ & & 100.00 & \\
\hline
\end{tabular}

representing reaction kinetics of almost all chemical, thermo-chemical reactions in the pyrolysis furnace.

SPYRO $^{\circledR}$ is now used by more than $85 \%$ of the ethylene producing industry worldwide. The latest program version and kinetic model SPYRO ${ }^{\circledR}-7$ covers all hydrocarbon species from C2 to C42 and more than 7000 reactions. This version also allows better flexibility in establishing the furnace and heat recovery flowsheet.

\section{Fundamentals of Thermal Cracking}

For the sake of completeness, we are recapping the fundamentals of thermal cracking from paper Part I (1) in this section [4].

1) Bond Energy

Bond energy is a measure of bond strength in a chemical bond. The larger the bond energy, the stronger the bond and hence the higher temperature required to break it. The bond energy is essentially the average enthalpy change for a gas reaction to break all the similar bonds. For the methane molecule, $\mathrm{CH}_{3}-\mathrm{H}, 104$ kcal is required to break the first single $\mathrm{C}-\mathrm{H}$ bond for a mole of methane, but breaking all four $\mathrm{C}-\mathrm{H}$ bonds for a mole of methane requires $397 \mathrm{kcal}$. Thus, the average bond energy is (397/4) 99 (not 104) kcal/mol.

2) Bond Length

Distance between centers of bounded atoms is called bond length. There is a general trend in that the shorter the bond length, the higher the bond energy. Some typical bond lengths and bond energies are given below to illustrate a general trend (Table 6 and Table 7). 
Table 6. Bond length and bond energy.

\begin{tabular}{ccc}
\hline Bond Type & Bond Length Picometer $\mathbf{( p m )}, \mathbf{1} \mathbf{~ p m ~} \mathbf{1 0}^{\mathbf{- 1 2}} \mathbf{~ m}$ & Bond Energy Kcal/mol \\
\hline H-H & 74 & 104 \\
H-C & 109 & 99 \\
C-C & 154 & 83 \\
C=C & 134 & 147 \\
C $\equiv$ C & 120 & 200 \\
\hline
\end{tabular}

Table 7. Bond energy of chemicals, Kcal/mol.

\begin{tabular}{|c|c|c|c|c|c|c|c|}
\hline Atom or Group & $\mathbf{H}$ & $\mathrm{CH}_{3}$ & $\mathrm{C}_{2} \mathrm{H}_{5}$ & $\left(\mathrm{CH}_{3}\right)_{2} \mathrm{CH}$ & $\left(\mathrm{CH}_{3}\right)_{3} \mathrm{C}$ & $\mathrm{C}_{6} \mathrm{H}_{5}$ & $\mathbf{C}_{6} \mathbf{H}_{5} \mathbf{C H}_{2}$ \\
\hline $\mathbf{H}$ & 104 & 103 & 98 & 95 & 93 & 110 & 85 \\
\hline $\mathrm{CH}_{3}$ & 103 & 88 & 85 & 84 & 81 & 101 & 73 \\
\hline $\mathrm{C}_{2} \mathrm{H}_{5}$ & 98 & 85 & 82 & 81 & 78 & 99 & 71 \\
\hline$\left(\mathrm{CH}_{3}\right)_{2} \mathrm{CH}$ & 95 & 84 & 81 & 79 & 74 & 97 & 70 \\
\hline$\left(\mathrm{CH}_{3}\right)_{3} \mathrm{C}$ & 93 & 81 & 78 & 74 & 68 & 94 & 67 \\
\hline $\mathrm{C}_{6} \mathrm{H}_{5}$ & 110 & 101 & 99 & 97 & 94 & 110 & 83 \\
\hline $\mathrm{C}_{6} \mathrm{H}_{5} \mathrm{CH}_{2}$ & 85 & 73 & 71 & 70 & 67 & 83 & 59 \\
\hline
\end{tabular}

$\mathrm{CH}_{3}$ : -methyl: $\mathrm{C}_{2} \mathrm{H}_{5}$ : -ethyl:( $\left(\mathrm{CH}_{3}\right)_{2} \mathrm{CH}$ : i-propyl $\left(\mathrm{CH}_{3}\right)_{3} \mathrm{C}$ : -t-butyl $\mathrm{C}_{6} \mathrm{H}_{5}$ : -phenyl $\mathrm{C}_{6} \mathrm{H}_{5} \mathrm{CH}_{2}$ : -benzyl.

3) Temperature Index

Temperature Index (TI) represents the mixed feed temperature reduction due to the thermal cracking and chemical reaction in the adiabatic zone i.e. crossover piping volume (CPV).

4) General Cracking Rules

a) Bond energy comparison between different atoms

$\mathrm{H}-\mathrm{H}>\mathrm{C}-\mathrm{H}>\mathrm{C}-\mathrm{C}$ (C-C is easier to break)

b) Dehydrogenation ability of HC depends upon its structure and is in the order of:

Tertiary $\mathrm{H}>$ Secondary $\mathrm{H}>$ Primary $\mathrm{H}$

c) For carbon-carbon bonds, the order of bond energy:

Triple Bond $>$ Double Bond $>$ Single Bond

d) Order of heat stability for paraffin is:

$\mathrm{CH}_{4}>\mathrm{C}_{2} \mathrm{H}_{6}>\mathrm{C}_{3} \mathrm{H}_{8}>\mathrm{C}_{4} \mathrm{H}_{10}>$

e) For $\mathrm{HC}$ with same $\mathrm{C}$ atoms, heat stability order is:

Aromatics $>$ Naphthene $>$ Di-Olefin $>$ Olefin $>$ Paraffin

\section{Simulation Results}

1) Effect of feed composition and mixed feed inlet temperature on the thermal cracking and MFPH coil material selection.

Data in Table 8 indicates there are three different reactions in the MFPH coil and CPV for Case 1 feed.

a) Steam-HC reforming reactions which are irreversible reactions at normal condition.

b) Methane reacts with water steam to form carbon monoxide and hydrogen (the mixture of $\mathrm{CO}$ and $\mathrm{H}_{2}$ is known as syngas), which is a reversible chemical reaction, $\mathrm{CH}_{4}+\mathrm{H}_{2} \mathrm{O} \rightleftharpoons \mathrm{CO}+3 \mathrm{H}_{2}$.

c) Water-gas shift reaction (WGSR) is a reversible chemical reaction in which carbon monoxide reacts with water vapor to form carbon dioxide and hydrogen, $\mathrm{CO}+\mathrm{H}_{2} \mathrm{O} \rightleftharpoons \mathrm{CO}_{2}+\mathrm{H}_{2}$.

Table 9 shows there is no thermal cracking for Case 2 feed because methane is stable and there are no non-methane hydrocarbons, such as ethane, propane, etc in the feed.

However, Reverse Water-Gas Shift (RWGS) reaction, $\mathrm{CO}_{2}+\mathrm{H}_{2} \rightarrow \mathrm{CO}+\mathrm{H}_{2} \mathrm{O}$, which is an endothermic reaction, can be involved in both MFPH coil and crossover piping volume as shown in Table 9. 
Table 8. Case 1 Stream composition at different locations.

\begin{tabular}{|c|c|c|c|}
\hline Location & Mixed Feed to MFPH & MFPH Outlet & Outlet of Cross Over Piping \\
\hline Mixed FeedFlow, Kg/h & 127,097 & 127,097 & 127,097 \\
\hline \multicolumn{4}{|c|}{ Composition mol\% (wet) } \\
\hline Hydrogen & 0.8500 & 0.8499758 & 0.8512 \\
\hline Methane & 26.0000 & 25.9999995 & 25.9998 \\
\hline Ethylene & - & 0.0000045 & 0.0031 \\
\hline Ethane & 0.3800 & 0.3799983 & 0.3791 \\
\hline Propylene & - & 0.0000020 & 0.0015 \\
\hline Propane & 0.0500 & 0.0499983 & 0.0487 \\
\hline Butenes & - & 0.0000008 & 0.0004 \\
\hline Butanes & 0.0200 & 0.0199987 & 0.0190 \\
\hline n-Hexane & 0.0100 & 0.0099988 & 0.0092 \\
\hline 1-Pentene & - & 0.0000001 & 0.0001 \\
\hline Carbon Monoxide & - & 0.0000286 & 0.0017 \\
\hline Carbon Dioxide & 0.4900 & 0.4899714 & 0.4883 \\
\hline Nitrogen & 0.5500 & 0.5500000 & 0.5500 \\
\hline Water & 71.6500 & 71.6500230 & 71.6478 \\
\hline Total & 100.0000 & 99.9999998 & 100.0000 \\
\hline Total Olefins & - & 0.0000074 & 0.0051 \\
\hline Temperature ${ }^{\circ} \mathrm{C}$ & 368.4 & 593.5 & 593.3 \\
\hline
\end{tabular}

Table 9. Case 2 stream composition at different locations.

\begin{tabular}{cccc}
\hline Location & Mixed Feed to MFPH & MFPH Outlet & Outlet of Cross Over Piping \\
\hline Mixed FeedFlow, Kg/h & 111,312 & 111,312 & 111,312 \\
Hydrogen & Composition mol\% (wet) & $\mathbf{7 . 1 8 6 4}$ \\
Methane & $\mathbf{7 . 2 5}$ & $\mathbf{7 . 2 4 6 4}$ & 26.2300 \\
Carbon Monoxide & 26.23 & 26.2300 & $\mathbf{0 . 1 0 3 6}$ \\
Carbon Dioxide & $\mathbf{0 . 0 4}$ & $\mathbf{0 . 0 4 3 6}$ & $\mathbf{2 . 1 5 6 4}$ \\
Nitrogen & $\mathbf{2 . 2 2}$ & $\mathbf{2 . 2 1 6 4}$ & 0.5700 \\
Water $^{\text {Total }}$ & 0.57 & 0.5700 & $\mathbf{6 3 . 7 5 3 6}$ \\
Temperature $^{\circ} \mathrm{C}$ & $\mathbf{6 3 . 6 9}$ & $\mathbf{6 3 . 6 9 3 6}$ & 100.0000 \\
\hline
\end{tabular}

Table 10 and Table 11 list the maximum tubewall temperature profiles for Cases 1 and 2, respectively.

2) Effect of crossover piping volume on cracking

The effect of SMR crossover piping volume on the mixed feed thermal cracking is shown in Figure 2. Case 1 feed is used for the study. 


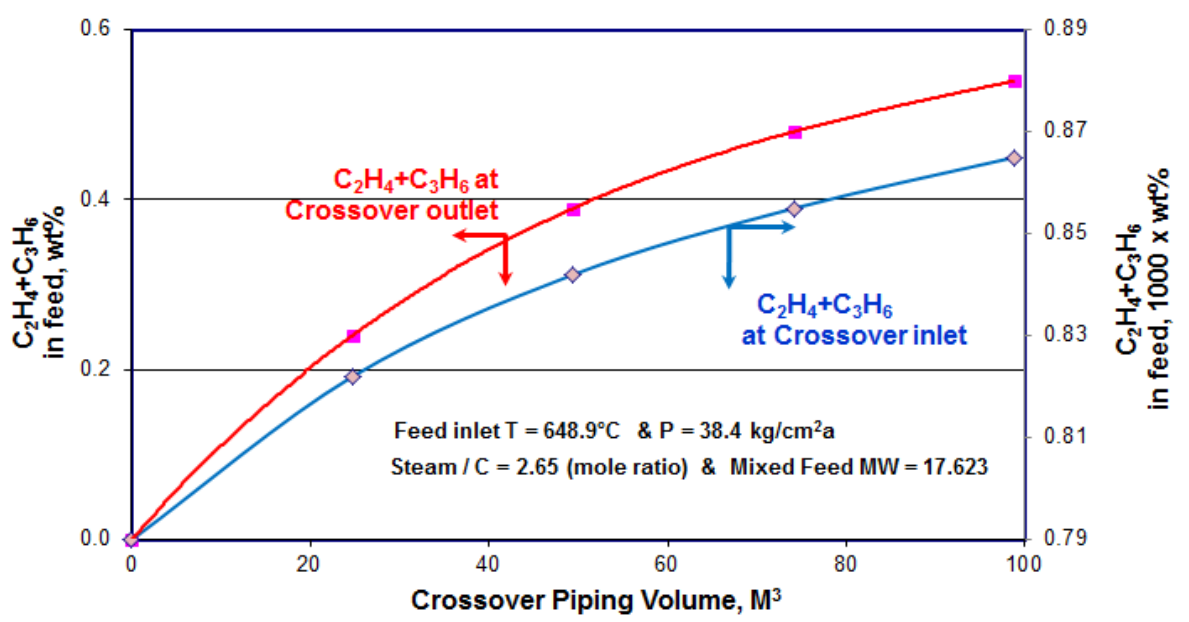

Figure 2. Effect of CPV on case 1 feed thermal cracking.

Table 10. Case 1 MFPH max tubewall temperature (MTT).

\begin{tabular}{|c|c|c|c|c|c|}
\hline \multirow{2}{*}{ No. of Rows } & \multicolumn{5}{|c|}{ Case 1} \\
\hline & Mixed Feed Temp, ${ }^{\circ} \mathrm{C}$ & Flue Gas Temp. ${ }^{\circ} \mathrm{C}$ & Simulation MTT, ${ }^{\circ} \mathrm{C}$ & Design Temp, ${ }^{\circ} \mathrm{C}$ & Material \\
\hline Row 8 & 593.5 (outlet) & 821.7 (outlet) & 646.7 & & \\
\hline Row 7 & & & 633.9 & 743.9 & $800 \mathrm{H}$ Sch 80 \\
\hline Row 6 & & & 616.1 & & \\
\hline Row 5 & & & 643.3 & & \\
\hline Row 4 & & & 596.1 & 693.9 & $800 \mathrm{H}$ Sch 40 \\
\hline Row 3 & & & 556.1 & & \\
\hline Row 2 & & & 614.4 & 7120 & OоOH Sch 00 \\
\hline Row 1 & 368.4 (inlet) & 1003.3 (inlet) & 612.2 & 143.9 & $800 \mathrm{H}$ SСП 80 \\
\hline
\end{tabular}

Table 11. Case 2 MFPH max tubewall temperature (MTT).

\begin{tabular}{|c|c|c|c|c|c|}
\hline \multirow{2}{*}{ No. of Rows } & \multicolumn{5}{|c|}{ Case 2} \\
\hline & Mixed Feed Temp, ${ }^{\circ} \mathrm{C}$ & Flue Gas Temp. ${ }^{\circ} \mathrm{C}$ & Simulation MTT, ${ }^{\circ} \mathrm{C}$ & Design Temp, ${ }^{\circ} \mathrm{C}$ & Material \\
\hline Row 8 & 649.3 (outlet) & 842.2 (outlet) & 689.4 & & \\
\hline Row 7 & & & 678.3 & 743.9 & $800 \mathrm{H}$ Sch 80 \\
\hline Row 6 & & & 663.3 & & \\
\hline Row 5 & & & 640.0 & & \\
\hline Row 4 & & & 645.0 & 693.9 & $800 \mathrm{H}$ Sch 40 \\
\hline Row 3 & & & 611.7 & & \\
\hline Row 2 & & & 661.1 & 7100 & م \\
\hline Row 1 & 456.4 (inlet) & 1001.1 (inlet) & 661.7 & 743.9 & $800 \mathrm{H}$ SCn 80 \\
\hline
\end{tabular}

For constant mixed feed flowrate, the residence time of mixed feed in the crossover piping is decided by the crossover piping volume, which depends on the crossover piping dimension and the distance from convection section outlet (Point A in Figure 1) to the reformer inlet location (Point B in Figure 1).

Table 12 shows that the larger CPV will have the longer residence time and hence the more light olefins $\left(\mathrm{C}_{2} \mathrm{H}_{4}+\mathrm{C}_{3} \mathrm{H}_{6}\right)$ formed in CPV. 
Table 12. Effect of CPV on Case 1 feed cracking.

\begin{tabular}{cccccc}
\hline Mixed feed flowrate, $\mathrm{kg} / \mathrm{h}$ & \multicolumn{5}{c}{127,090 (Case 1) } \\
\hline Crossover Piping Volume (CPV), ${ }^{3}$ & 0.0 & 24.7 & 49.4 & 74.1 & 98.8 \\
\hline MFPH outlet temperature, ${ }^{\circ} \mathbf{C}$ & $\mathbf{6 4 8 . 9}$ & $\mathbf{6 4 9 . 9}$ & $\mathbf{6 5 0 . 5}$ & $\mathbf{6 5 0 . 9}$ & $\mathbf{6 5 1 . 2}$ \\
Residence time in CPV, sec & 0.0 & 6.0 & 12.0 & 18.0 & 24.0 \\
Mixed feed T drop in CPV, ${ }^{\circ} \mathbf{C}$ & $\mathbf{0 . 0}$ & $-\mathbf{1 . 0}$ & $\mathbf{- 1 . 6}$ & $-\mathbf{2 . 0}$ & $-\mathbf{2 . 2 7}$ \\
${\text { Mixed feed T at SMR inlet, }{ }^{\circ} \mathbf{C}}$ & $\mathbf{6 4 8 . 9}$ & $\mathbf{6 4 8 . 9}$ & $\mathbf{6 4 8 . 9}$ & $\mathbf{6 4 8 . 9}$ & $\mathbf{6 4 8 . 9}$ \\
$\mathrm{C}_{2} \mathrm{H}_{4}+\mathrm{C}_{3} \mathrm{H}_{6}$ at MFPH outlet, wt\% (dry) & $7.90 \mathrm{E}-4$ & $8.22 \mathrm{E}-4$ & $8.42 \mathrm{E}-4$ & $8.55 \mathrm{E}-4$ & $8.65 \mathrm{E}-4$ \\
$\mathrm{C}_{2} \mathrm{H}_{4}+\mathrm{C}_{3} \mathrm{H}_{6}$ formed in CPV, wt\% (dry) & 0.0 & 0.239 & 0.389 & 0.479 & 0.539 \\
$\mathbf{C}_{2} \mathbf{H}_{4}+\mathbf{C}_{3} \mathbf{H}_{6}$ at SMR inlet, wt\% (dry) & $\mathbf{7 . 9 0 E - 4}$ & $\mathbf{0 . 2 4}$ & $\mathbf{0 . 3 9}$ & $\mathbf{0 . 4 8}$ & $\mathbf{0 . 5 4}$ \\
\hline
\end{tabular}

Therefore, it is better to keep the CPV as small as possible to avoid higher light olefins entering into the reformer.

The mixed feed temperature at the reformer inlet is equal to the MFPH feed outlet temperature minus the mixed feed temperature drop in the crossover piping volume.

\section{Conclusions}

1) There is not only thermal cracking but also chemical reaction in the MFPH coil and crossover piping volume which is an adiabatic zone.

2) There is a slight thermal cracking and chemical reactions in both MFPH coil and crossover volume for Case 1 and Temperature Index (TI) is $0.2^{\circ} \mathrm{C}$.

3) There is no thermal cracking for Case 2 feed because of non-methane hydrocarbons in the feed. However, Reverse Water-Gas Shift (RWGS) reaction, which is an endothermic reaction, can be involved in both MFPH coil and crossover volume. Hydrogen reacts with carbon dioxide to form carbon monoxide and water vapor and $\mathrm{TI}$ is $0.4^{\circ} \mathrm{C}$.

4) Larger Crossover Piping Volume results in a higher temperature reduction in the adiabatic zone and therefore, more light olefins to the reformer and easy to form coke in reformer tubes.

5) Maximum tubewall temperature profiles for MFPH coil are useful to select the correct tube material.

\section{References}

[1] Zhang, G.T. and Sekhri, S. (2011) Optimization of Reformer Inlet Temperature Based on Thermal Cracking of Feedstocks. Presented at CET2011 World Congress on Engineering and Technology, Shanghai, 28 October-2 November 2011, Paper ID \#23177.

[2] Sekhri, S., et al. (1993) Steam Reforming-A Flexible Solution. NPRA 1993 Annual Meeting, Texas, AM-93-23.

[3] Zhang, G.T. and Evans, B. (2008) Impact of Cracking at the Inlet and Outlet Transitions of Ethylene Furnace Radiant Sections. Presented at Technip Ethylene Technology and SPYRO International Conference, Abu Dhabi, 30 January 2008.

[4] Zhang, G.T. and Evans, B. (2012) Progress of Modern Pyrolysis Furnace Technology. Presented at CET2012 World Congress on Engineering and Technology, Beijing, 26-28 October 2012, Paper ID \#71086. http://dx.doi.org/10.4236/ampc.2012.24b044 